\title{
Effects of Partial Saturation on Nitrogen Removal and Bacterial Community in Vertical-Flow Constructed Wetlands
}

Khadija kraiem ( $\nabla$ kraiemkhadija@gmail.com )

Higher Institue of applied Biological Sciences https://orcid.org/0000-0002-2307-186X

Hamadi Kallali

CERTE: Centre de Recherche et des Technologies des Eaux de Borj Cedria

Rim Werheni Ammeri

CERTE: Centre de Recherche et des Technologies des Eaux de Borj Cedria

salma Bessadok

Universite de Tunis El Manar Faculte des Sciences de Tunis

Naceur Jedidi

CERTE: Centre de Recherche et des Technologies des Eaux de Borj Cedria

\section{Research Article}

Keywords: Constructed wetlands, Rural wastewater, Saturated bed, Nitrogen, nitrification, denitrification

Posted Date: September 20th, 2021

DOI: https://doi.org/10.21203/rs.3.rs-854531/v1

License: (c) (i) This work is licensed under a Creative Commons Attribution 4.0 International License. Read Full License 


\section{Abstract}

The laboratory-scale pilot of constructed wetlands has been in operation for six months; (1) an unsaturated vertical flow constructed wetland (UVF-CW), this system was used to represent the classic vertical constructed wetlands, (2) a saturated vertical flow constructed wetland (SVF-CW), to evaluate the effects of the saturated condition on nitrogen removal and composition of the microbial community. The results showed that the saturation condition positiveley influenced the removal efficiencies of the nitrogen, the aeverage removal rate of the total kjeldahl nitrogen increased from $56 \%$ in unsaturated vertical flow constructed wetland (UVF-CW) to $63 \%$ in saturated vertical flow constructed wetland (SVF$\mathrm{CW}$ ). In addition, the microbial communities also was affected by the saturation condition, the relative abundances of nitrifying bacterium in UVF-CW are 13.8\% (Nitrosomonas), 7.2\% (Nitrosospira), 18.1\% (Nitrospira) and 15.3\% (Nitrobacter). In contrast, in SVF-CW, Nitrosomonas, Nitrosospira, Nitrospira and Nitrobacter only accounted for $6.8 \%, 5.6 \%, 7.4 \%$ and $10.6 \%$ respectively. However, the saturation condition seemed to increase denitrifying bacterium more than three times, in unsaturated vertical flow constructed wetland, only Pseudomonas (6.5\%) and Paracoccus (4.85\%) were detected, but in saturated vertical flow constructed wetland (SVF-CW), the abundance of Pseudomonas $(13.08 \%)$ and Paracoccus $(9.74 \%)$ were increased, and three other groups of denitrifying bacteria were also detected as Zoogloea (3.32\%), Thauera (5.41\%) and Thiobacillus (3).

\section{Introduction}

Excess nitrogen in aquatic ecosystems can cause many problems such as eutrophication,which have negatively affect on biodiversity,climate and human health (Stevens et al. 2019). Therefore, the remove of nitrogen from waste water it is necessary. Traditional activated sludge technology has been used for nitrogen removal in multiple wastewater treatment plants (WWTPS) due to its high efficiency (EPA, 1993). However, these conventional technologies require high construction cost and consume more energy (Liu et al. 2016).

In recent years, constructed wetland (CW) is an ecological technology. Due to its various advantages over traditional wastewater treatment technologies, it has been rapidly developed in wastewater treatment in scattered areas in industrialized counties and low-income countries (Liu et al. 2016 ; Zhang et al. 2019). These include low construction and operating cost, easier maintenance and good integration into the landscape and promotion of biodiversity (Álvarez et al. 2017; Paing et al. 2015). However, the removal of nitrogen in constructed wetlands (CWs) exhibits large fluctuations and is often unsatisfactory (Wang et al. 2017). The total nitrogen removal in vertical flow or in horizontal flow constructed wetlands is usually not completely removal, but instead converts it to various nitrogen compounds (Pelissari et al. 2017).

In fact, the vertical flow constructed wetlands is an unsaturated systems, which often fed with several pulses intermittently throughout the day, resulting in a high oxygen transmission capacity, that is beneficial to the nitrifying bacteria in the bed (Platzer et al. 1999). However, horizontal flow constructed wetlands are mainly operated under anoxic/anaerobic conditions, which makes it a suitable environment 
for denitrification process (Vymazal et al. 2007). Generally, the nitrogen removal limitation in constructed wetlands can be explained by the competition for oxygen by autotrophic and heterotrophic microorganisms heterotrophic (Saeed et al. 2012), and the limit of organic carbon available for the process of denitrification (Lavrova et al. 2010). Vertical flow constructed wetlands have more attention than horizontal flow constructed wetlands due to its less demand for land (Meng et al. 2014). On the other hand, traditional vertical flow constructed wetlands cannot remove total nitrogen (TN) satisfactorily due to the lack of appropriate hypoxic conditions for denitrification (Pelissari et al. 2017)

In order to completely remove nitrogen, various types of enhanced vertical flow constructed wetlands have been studied, such as artificial aeration, tidal flow and integrated vertical flow constructed wetlands (Pelissari et al. 2018; Hu et al. 2016). There are other operational conditions to enhance the removal efficiency of total nitrogen in vertical flow constructed wetlands, such as recirculation of effluent to improve nitrification efficiency ( Wu et al. 2016) and stepwise feed to enhance carbon source supply to promote denitrification ( $\mathrm{Li}$ et al. 2017). However, these modifications have increased operating costs and maintenance complexity. The latter strategy uses a partially saturated vertical flow constructed wetland configuration to create anoxic/anaerobic conditions at the bottom of the bed and aerobic conditions at the top of the bed to promote adequate condition for simultaneous nitrification and denitrification (Torrijos et al. 2017; Kim et al. 2014). This model is more efficient in total nitrogen removal than traditional unsaturated vertical flow constructed wetlands with sequential nitrification and denitrification (Silveira et al. 2015; Dong et al. 2007; Kim et al. 2015a).

In general, all efforts aimed at maximizing the nitrogen removal in constructed wetlands are directly related to the activities of enhancing microbial communities, which are responsible for the conversion of various nutrients in the filter media and rhizosphere biomass (Mayo et al. 2005). Many studies have evaluated the dynamics of bacterial communities in constructed wetlands. Foladori et al. (2015) showed that the number of viable bacteria in the surface layer is 3.7 times that of the deep layer. Adrados et al. (2014) characterized the prokaryotic microbial communities of vertical flow constructed wetlands, horizontal constructed wetlands and biological filter sand, and reported higher bacterial activity than archaea in all research systems. Other studies have shown that the diversity of bacterial communities in constructed wetlands may affect the quality of the final effluent (Calheiros et al. 2009). Button et al. (2015) indicated that microbial metabolic functions identified in different constructed wetlands types are related to the design of each system, spatial position within the bed, and especially with levels of pretreatment.

There is no rigorous research on the knowledge of nitrogen-transforming bacteria in vertical constructed wetlands. Therefore, it is clearly necessary to further understand the kinetics of nitrogen conversion bacteria in unsaturated vertical flow constructed wetlands, especially in partially saturated vertical flow constructed wetlands, in order to increase the total nitrogen removal in a single vertical flow constructed wetland. The purpose of this study is to: (1) compare the conversion and removal efficiency of nitrogen in saturated and unsaturated vertical flow constructed wetlands; (2) identify nitrifying and denitrifying bacteria covered with gravel in unsaturated and saturated zones. 


\section{Materiel And Methods}

\subsection{VFCW systems and operation design}

Two laboratory-scale vertical flow constructed wetlands (VFCW) were evaluated in duplicate with the same size and substrate. They operate in parallel, where unit 1 is composed of a partial vertical flow wetland (SVF-CW) (50\%), and unit 2 is composed of a traditional unsaturated vertical flow wetland (UVF$\mathrm{CW})$. A schematic diagram of the laboratory scale of VFCWs is shown in Fig. 1. The two laboratory-scale constructed wetlands are made of polyvinyl chloride tube, each having a diameter of $41 \mathrm{~cm}$, a total height of $100 \mathrm{~cm}$, and a media bed height of $80 \mathrm{~cm}$. These units are equipped with a $10 \mathrm{~cm}$ coarse gravel (25 to $40 \mathrm{~mm}$ ) drainage layer at the bottom and a $70 \mathrm{~cm}$ main filter layer composed of 2-4 mm gravel. The downwardly applied saturation zone is maintained by the siphon structure at the outlet. Young reed species are collected from local valleys and planted in all vertical flow wetlands.

In order to the growth of plants and biofilms in the medium, the wetland has accumulated water for up to 2 months ( $50 \%$ of rural wastewater and $50 \%$ of tap water). After the adaptation period, these systems intermittently fed with rural wastewater at a flow rate of $20 \mathrm{~L} / \mathrm{d}$ (five batches per day). The operation cycle is divided into a feeding period ( 3 days) and a rest period (4 days).Table 1 shows the chemical characteristics of influent wastewatercycle was divided into a feeding period (3 days) and a rest period (4 days).Table 1 shows the chemical characteristics of the influent wastewater.

Table 1

Characteristics of influent wastewater.

\begin{tabular}{|c|c|c|c|c|c|c|}
\hline & $\mathrm{DCO}(\mathrm{mg} / \mathrm{L})$ & $\mathrm{pH}$ & $\begin{array}{l}\mathrm{NH}_{4}^{+} \\
(\mathrm{mg} / \mathrm{L})\end{array}$ & $\begin{array}{l}\mathrm{NO}_{3}^{-} \\
(\mathrm{mg} / \mathrm{L})\end{array}$ & $\begin{array}{l}\mathrm{NO}_{2}^{-} \\
(\mathrm{mg} / \mathrm{L})\end{array}$ & $\begin{array}{l}\text { TNK } \\
(\mathrm{mg} / \mathrm{L})\end{array}$ \\
\hline Range & $1040-1180$ & $6, .98-8$ & $151-204$ & $1.9-5.4$ & $0-0.1$ & $173-230$ \\
\hline Mean & 1124 & 7.45 & 188 & 3.4 & 0.02 & 202 \\
\hline
\end{tabular}

\subsection{Pollutants Sampling and Analyses}

During the experiment, water samples were collected twice a week at the beginning and end of each feeding sequence, twice a week. The sample corresponds to a batch of feed. All water samples were filtered through $0.45 \mu \mathrm{m}$ cellulose acetate membrane before analysis. The method to determine the water parameters is as follows: According to the Kjeldahl method (Morre et al. 2010). The analysis of ammonium $\left(\mathrm{NH}_{4}{ }^{+}\right)$and nitrate $\left(\mathrm{NO}_{3}{ }^{-}\right)$was performed according to standard methods (APHA, 2012). The $\mathrm{pH}$ was determined by a $\mathrm{pH}$ meter (PHS-3C, China).

\subsection{Biomass sampling and bacteria detection}


For bacterial analysis of nitrifying and denitrifying communities, 20 grams of bed media were collected in all pilot plants at two different depths $(-20) \mathrm{cm}$ and $(-60) \mathrm{cm}$, and 100 milliliters of deionized water was added to it. The samples are mixed and sonicated in ultrasound for 5 minutes to loosen the biofilm from the medium. Then, the sample was centrifuged at $1500 \mathrm{~g}$ for 5 minutes. All biomass samples were prepared according to the standard method of fluorescence in situ hybridization (FISH) analysis (Zwirglmaier et al. 2005). To fix the samples, $1 \mathrm{ml}$ of each sample (mixed water and biofilm suspension) was centrifuged at $16,000 \mathrm{~g}$ for 5 minutes, and then, by adding paraformaldehyde solution (4\%) and phosphate buffered saline (PBS) 3:1, According to Amann (1995), the recovered particles were fixed at $4^{\circ} \mathrm{C}$ for 3 hours. Then, the fixed samples were washed twice with $1 \mathrm{~mL}$ of PBS and finally suspended in a solution of PBS and absolute ethanol and stored at $-20^{\circ} \mathrm{C}$.

For the quantification of total bacterial cells, considering the Eubacterial domain, a volume of $10 \mu \mathrm{l}$ of each sample was fixed on a PTFE-printed microscope slide and covered with $1 \mu \mathrm{g} . \mathrm{mL}^{-1}$ of 4', 6-diamidino2-benzene Based indole (DAPI) solution. Table 2 shows the specific probes for nitrifying and denitrifying bacterial communities used in this study. All probes are labeled with the fluorescent pigment Сy3 at the 5 position. The quantification of specific bacteria was performed by directly counting 20 random fields in each well using an epifluorescence microscope (OlympusBX41, Tokyo, Japan). In order to estimate the abundance of cells hybridized with the probe EUB mixture, the cells stained with DAPI were considered to represent $100 \%$ of all microorganisms identified by digital images. For the remaining probes, 20 regions were randomly selected, and the cells stained with the probe EUB mixture were considered to be $100 \%$ of all bacteria identified by the digital image. The "Microbial Ecology Digital Image Analysis (DAIME)" software was used to determine the relative abundance of nitrifying and denitrifying bacteria from the total DAPI staining (Daims et al. 2006)

Table 2

The different probes used in this study.

\begin{tabular}{|lll|}
\hline Probe & Probesequence; $\left(\mathbf{5}^{\prime} \rightarrow \mathbf{3}^{\prime}\right)$ & Targetedorganisms \\
\hline EUB338mix & GC(T/A)GCC(T/A)CCCGTAGG(A/T)GT & $\begin{array}{l}\text { Equimolar mixture of EUB338I EUB338II And } \\
\text { Bacteriadomain, Planctomycetales and } \\
\text { Verrucomicrobiales }\end{array}$ \\
\hline AER66 & CTACTTTCCCGCTGCCGC & Pseudomonas \\
\hline TBD121 & CTCGGTACGTTCCGACGC & Aeromonas \\
\hline NEU653 & CCCCTCTGCTGCACTCTA & Thiobacillus denitrificans \\
\hline NIT3 & CCTGTGCTCCATGCTCCG & Nitrosomonas \\
\hline Nsv443 & CCGTGACCGTTTCGTTCCG & Nitrobacter spp. \\
\hline PAR124 & GGATTAACCCACTGTCACC & Nitrosospira \\
\hline
\end{tabular}




\subsection{Statistical Analysis}

The average concentration and bacterial abundance were compared by the measured value \pm standard error. Use the statistical program STATISTICA software (http://www.statsoft.com) for statistical analysis. The average value was compared by Fisher'shsd test $(<0.05)$.

\section{Results And Discussion}

\subsection{Temperature and $\mathrm{pH}$}

During the experiment period, no significant correlation was observed between effluent temperature and saturated zone depth. The average effluent temperature was 23.5 and $25.2^{\circ} \mathrm{C}$ for SFV-CW and UFV-CW respectively. The temperature range in two VFCWs was suitable for nitrogen removal through nitrification and denitrification process (Kotti et al. 2010; Chang et al. 2013; Huang et al. 2013). The effluent pH was not significantly different in two VFCWs $(p>0.05)$. The $\mathrm{pH}$ value of VFCWs is $6.98-7.12$, which is slightly lower than the $\mathrm{pH}$ value of the influent 7.31 (Table 3). The $\mathrm{pH}$ range of $6.87-7.31$ was favorable for microbial nitrification and denitrification (Saeed et al. 2012).

Table 3

Influent and effluent of $\mathrm{pH}$ and temperature Influent concentrations

(means \pm standard deviation)

\begin{tabular}{|llll|}
\hline Parameter & Influent & Effluent SVF-CW & Effluent UVF-CW \\
\hline Temperature $\left(\mathrm{C}^{\circ}\right)$ & $21.74 \pm 2$ & $23.5 \pm 1.1$ & $25.2 \pm 2.3$ \\
$\mathrm{pH}$ & $7.31 \pm 0.9$ & $7 . .02 \pm 1.8$ & $6.87 \pm 1.2$ \\
\hline
\end{tabular}

\subsection{Nitrogen Removal}

There are significant differences in the removal effect of $\mathrm{NH} 4+-\mathrm{N}$ between the two vertical flow constructed wetlands $(p<0.05)$. The $\mathrm{NH}_{4}{ }^{+}-\mathrm{N}$ removal efficiency of UVF-CW and SVF-CW $76.85 \%$ and $63.45 \%$ respectively (Table 4). The removal of NH4+-N largely depends on the depth of the saturation zone. The removal efficiency of ammonium increases as the depth of the saturation zone decreases. Several studies have shown similar finding (Pelissari et al. 2017; Huang et al. 2017). However, these results are inconsistent with those obtained by Pelissari et al.(2018) who pointed out that there is no significant difference in ammonium removal efficiency (unsaturated vertical flow and saturated vertical flow approximately $69 \%(p=0.928)$ ). 
Table 4

Nitrogen concentration at Influent and effluent and removal efficiency of the partially saturated vertical constructed wetland (SVF-CW) and unsaturated vertical constructed wetland (UVF-CW)

\begin{tabular}{|llllll|}
\hline Parameter & Influent wastewater $\left(\mathbf{m g . L}^{-1}\right)$ & \multicolumn{2}{l}{ Effluent $\left(\mathbf{m g . L ^ { - 1 }}\right)$} & \multicolumn{2}{l|}{ Removal efficiency (\%) } \\
\cline { 3 - 6 } & & UVF-CW & SVF-CW & UVF-CW & SVF-CW \\
\hline $\mathrm{TNK}$ & $202 \pm 51.3$ & $71 \pm 31.3$ & $54 \pm 20.3$ & $56 \pm 1.7$ & $63 \pm 2.71$ \\
\hline $\mathrm{NH}_{4}{ }^{+}-\mathrm{N}$ & $178 \pm 42.1$ & $41.2 \pm 1.6$ & $65.05 \pm 0.2$ & $41.2 \pm 1.6$ & $65.05 \pm 0.2$ \\
\hline $\mathrm{NO}_{3}{ }^{-}-\mathrm{N}$ & $3.6 \pm 0.8$ & $17.56 \pm 2.3$ & $4.26 \pm 1.41$ & - & - \\
\hline $\mathrm{NO}_{2}{ }^{-}-\mathrm{N}$ & $0.02 \pm 0.1$ & $0.86 \pm 1.5$ & $0.1 \pm 1.3$ & - & - \\
\hline
\end{tabular}

The unsaturated vertical flow (UVF-CW) had higher ammonium removal efficiencies than partially saturated vertical flow (SVF-CW). This result can be attributed to the higher diffusion of oxygen to the partially unsaturated layer, which is beneficial to the nitrifier development (Kraiem et al. 2019).

In contrary, increasing saturation level seemed to have a positive effect on Total Kjeldahl Nitrogen (TKN) removal efficiency. In fact, vertical flow constructed wetlands with saturated layer (SVF-CW) had higher NTK removal than unsaturated bed (UVF-CW) (Table 4). This higher removal efficiency resulted from the development of denitrification process in saturated layer (Pelissari et al. 2017; Del Toro et al. 2019).

With regard to $\mathrm{NO}_{2}^{-}-\mathrm{N}$, this form of nitrogen showed that an increase at both configurations of the systems with respect to the influent, $\mathrm{NO}^{-} \mathrm{N}$ concentration in the effluents remained above the values in the influent. Due to the fact, this oxidized form of nitrogen is only an intermediate in different nitrogen reaction transformations; it is understandable to find such very low concentrations in this study.

There are significant differences in the removal effect of $\mathrm{NO}_{3}{ }^{-}-\mathrm{N}$ between the two vertical flow constructed wetlands $(\mathrm{p}<0.05)$. Table 4 , shows that the removal efficiency of SVF-CW on $\mathrm{NO}_{3}{ }^{-} \mathrm{N}$ is significantly higher than that of UVF-CW $(P<0.05)$,indicating that denitrification capacity in the vertical flow constructed wetlands was promoted significantly with the saturated layer. This can be explained by the fact that the saturation layer is produced the required hypoxic condition and enhanced denitrification activity. This finding is consistent with the research conducted in the subsurface vertical flow constructed wetlands (Pelissari et al. 2018). In addition, although autotrophic nitrification-heterotrophic denitrification is the main process of SVF-CW nitrogen removal, other mechanisms probably took place in this system. Other possible mechanisms are ANAMMOX, which could $\mathrm{NO}_{3}{ }^{-} \mathrm{N}$ produce (Dong et al. 2007; Kraiem et al. 2019). The increased of nitrate concentration in UVF-CW confirms a lightly higher capacity of UVF-CW for nitrification due to supplementary oxygenation through the unsaturated layer.

\subsection{Influence of Partially Saturated on Nitrifying and Denitrifying Bacterial Communities}


In constructed wetlands, the diversity and abundance of microbial communities depends on environmental factors, wastewater types, media types, operating conditions and plant species (Meng et al. 2014). Aerobic conditions (inside the media) often support autotrophic nitrification in vertical flow constructed wetlands (Wu et al. 2016; Kizito et al. 2017). In order to better understand the remove of nitrogen obtained in two units with different saturation levels (UVF-CW and SVF-CW), (FISH) analysis were used in this study. Figure 2 shows that the detection of nitrifying bacteria by FISH technology, which shows that higher relative abundance of nitrifying bacteria and higher ratio of nitrite oxidizing bacteria (NOB) to Ammonium oxidizing bacteria (AOB) followed by higher ammonium removal performance were obtained in UVF-CW compared to SVF-CW.

The relative abundances of nitrifying bacteria were significantly different among the two different vertical flow constructed wetlands $(\mathrm{p}<0.05)$. The relative abundances in UVF-CWwere13.8\%(Nitrosomonas),7.2\% (Nitrosospira), 18.1\% (Nitrospira) and15.3\% (Nitrobacter).On the contrary, Nitrosomonas, Nitrosospira,Nitrospira and Nitrobacter merely accounted for $6.8 \%, 5.6 \%, 7.4 \%$ and $10.6 \%$ of the total bacteria in SVF respectively (Fig. 3). These abundances are higher than that obtained by Guan et al. (2015), Wang et al. (2016) and Pelissari et al. (2017)

The presence of saturated media, resulting the reduction of the aerobic zone (entering the media) (Vymazal and Kröpfelová, 2015) which could have played a major role in reducing nitrifying bacteria. This result confirmed the nitrification performance obtained in Sect. 3.4. These results also indicated that Nitrosomonas in the two vertical flow constructed wetlands ((UVF-CW and SVF-CW) was more abundant than Nitrosospira. This outcome can be explained by the high influent concentration of ammonium (Table 4), forming a community dominated by Nitrosomonas, with low substrate affinity but a high maximum activity than Nitrosospira ( Wang et al. 2016).

In contrary to nitrifying bacteria which deceased with increasing saturation level, the denitrifying bacteria increased with increasing of saturation depth. The relative abundances and variety of denitrifying microorganisms were significantly different among the two different vertical flow constructed wetlands $(p<0.05)$, Zhang et al. (2015) also observed similar findings. Furthermore, under saturated vertical constructed wetland (SVF-CW) denitrifying bacteria increased more than 3 times in comparison to unsaturated vertical constructed wetland (UVF-CW).. Foladori et al. (2015) showed that due to the different environmental condition of the bed mesdia along the vertical section, the depth has a great influence on the distribution of bacteria. In fact, in (UVF-CW), only Pseudomonas (6.5\%), and Paracoccus $(4.85 \%)$ were detected in this study (Fig. 4). These two bacteria are associated to the classic pathways of denitrification that carried out mainly by Pseudomonas spp. (Ahn, 2006) and with aerobic denitrification and heterotrophic nitrification by Paracoccus denitrificans ( Richardson, 2000).

However, in (SVF-CW), Pseudomonas (7\%) and Paracoccus (5\%) were increased in abundance but three other groups were also detected as Zoogloea (1.8\%), Thauera (2\%) and Thiobacillus (3\%), owing to low availability of oxygen seems to favor denitrifying bacteria (Fig. 4). These results indicated that, besides the classical pathways of denitrification, other pathways of denitrification also participated in nitrogen 
transformation in saturated zone. In fact, the detection of Thiobacillus, which can use inorganic compounds as source of carbon and compounds such as nitrates or nitrites as electron donors was associated to autotrophic denitrification (Pelissari et al. 2017).

\section{Conclusion}

Partially saturated (SVF-CW) configurations were developed to optimize the nitrogen removal in the same filter with low operation costs and low required area. This research highlighted that the application of saturation zone at the bottom can ensure nitrogen removal performance better than classic vertical flow constructed wetlands. FISH analysis in this study indicated that the diversity and the abundance of nitrifying and denitrifying bacteria were affected by the depth of saturated layer:

1. The average abundance of nitrifying bacteria in (UVF-CW) is higher than that in (SVF-CW). These results also showed that Nitrosomonas in the two systems was more abundant than Nitrosospira, this might be related to the high influent ammonium concentration, which leads, to form a community dominated by Nitrosomonas, and its substrate affinity lower, but the activity is higher than Nitrosospira.

2. A saturated zone influence was observed on relative abundances and diversity of denitrifying bacteria. In UVF-CW only Pseudomonas and Paracoccus were detected. However, in (SVF-CW), these bacteria were increased in abundance but three other groups were also detected as Zoogloea, Thauera and Thiobacillus.

3. In addition to the classic denitrification and nitrification, the occurrence of species as Paracoccus, Thiobacillus denitrificans and Thiobacillus thioparus have also been discovered, which are related to heterotrophic nitrification and aerobic and autotrophic denitrification.

This research is only carried out on a the laboratory scale, so, it is worthwhile to further study the removal effect and application of pilot scale and full scale to obtain more conclusive results. Other studies can focus on the effects of different factors that can improve the performance of nitrogen remove, such as plant species, substrate types. Our group is conducting further research on this topic, such as using a combination of fillers of natural materials (e.g. olive seeds, olive pomace, compost, clay, biochar) to improve the efficiency of nitrogen remove in the constructed wetland wetlands.

\section{Declarations}

\section{Acknowledgements}

We wish to thank the Tunisian Ministry of Higher Education and Scientific Research for financial support, and Effluent Treatment and Valorization Laboratory for operational support. We would also like to thank the editors and reviewers for their important comments, which enhanced the previous. 
Ethics approval and consent to participate :(Not applicable)

Consent for publication : (Not applicable)

Availability of data and materials : (Not applicable)

Competing interests : The authors declare that they have no competing interests

Funding : This research work is financially supported by the Tunisian Ministry of Higher Education, Scientific Research and Technologyersion of this manuscript.

Authors'contributions : Khadija Kraiem: contributed to the design and construction of the constructed wetland, to the analysis of the results and to the writing of the manuscript; Hamadi Kallali conceived of the presented idea; Rim Werheni Ammeri contributed to the interpretation of the results; Bessadok Salma: contributed to sample preparation; Naceur Jedidi: contributed to the final version of the manuscript.All authors discussed the results and contributed to the final manuscript

\section{References}

1. Adrados B, Sánchez O, Arias C A, Becares E, Garrido L, Mas J, Brix H, Morató J (2014) Microbial communities from different types of natural wastewater treatment systems: vertical and horizontal flow constructed wetlands and biofilters. Water Res. 55 : 304-312. https://doi.org/10.1016/j.watres.2014.02.011

2. Ahn Y H (2006) Sustainable nitrogen elimination biotechnologies: a review. Process Biochem. 41 (8) : 1709-1721. https://doi.org/10.1016/j.procbio.2006.03.033

3. Álvarez J A, Ávila C, Otter P, Kilian R, Rolletschek I D M, Molle P, Khalil N, Ameršek I, Mishra V K, Jorgensen C, Garfi A, Carvalho P, Arias C A (2017) Constructed wetlands and solar-driven disinfection technologies for sustainable wastewater treatment and reclamation in rural India: SWINGS project. Water Sci Technol. 76 (6) : 1474-1489. https://doi: 10.2166/wst.2017.329

4. APHA (2012) Standard methods for the examination of water and wastewater, 597 22th ed. American Public Health Association, Washington, DC, USA.

5. Amann R (1995) In situ identification of microorganism by whole cell hybridization with rRNAtargeted nucleic acid probes. In: Akkerman, A.D.L., van Elsas, J.D., de Bruijn, F.J. (Eds.), Molecular Microbial Ecology Manual. Kluwer Academic Publishers, Dodrecht, The Netherlands. pp. 1-15 3.3.6.

6. Button M, Nivala J, Weber K.P, Aubron T, Müller, R A (2015) Microbial community metabolic function in subsurface flow constructed wetlands of different designs. Ecol. Eng. $80: 162-171$.

https://doi.org/10.1016/j.ecoleng.2014.09.073

7. Calheiros C S C, Duque A F, Moura A, Henriques I S, Correia A, Rangel A O S S, Castro P M L (2009) Substrate effect on bacterial communities from constructed wetlands planted with Typha latifolia treating industrial wastewater. Ecol Eng. 35 (5) : 744-753.

https://doi.org/10.1016/j.ecoleng.2008.11.010 
8. Chang J. Wu S, Dai Y, Liang W, Wu Z, 2013. Nitrogen removal from nitrate-laden wastewater by integrated vertical-flow constructed wetland systems. Ecol Eng. 58 : 192-201. https://doi.org/10.1016/j.ecoleng.2013.06.039

9. Daims H, Lücker S, Wagner M (2006) Daime, a novel image analysis programfor microbial ecology and biofilm research. Environ Microbiol. 8 : 200-213. https://doi.org/10.1111/j.14622920.2005.00880.x

10. Del Toro A, Tejeda A, Zurita F ( 2019) Addition of corn cob in the free drainage zone of partially saturated vertical wetlands planted with I.sibirica for total nitrogen removal-a pilot-scale study. Water. 11(10) : 2151-2116. https://doi.org/10.3390/w11102151

11. Dong $Z$, Sun $T$ (2007) A potential new process for improving nitrogen removal in constructed wetlands-promoting coexistence of partialnitrification and ANAMMOX. Ecol Eng. 31 (2) : 69-78. https://doi.org/10.1016/j.ecoleng.2007.04.009

12. EPA (1993) Process Design Manual for Nitrogen Control. US EPA, Washington, DC.

13. Foladori P, Bruni L, Tamburini S (2015) Bacteria viability and decay in water and soil of vertical subsurface flow constructed wetlands. Ecol Eng. 82 : 49-56. https://doi.org/10.1016/j.ecoleng.2015.04.058

14. Guan W, Yin M, He T, Xie S (2015) Influence of substrate type on microbial community structure in vertical-flow constructed wetland treating polluted river water. Environ Sci Pollut Res. 22 : 1620216209.https://doi.org/10.1007/s11356-015-5160-9

15. Huang J, Cai W, Zhong Q, Wang S (2013) Influence of temperature on micro-environment, plant ecophysiology and nitrogen removal effect in subsurface flow constructed wetland. Ecol Eng. 60 : 242248. https://doi.org/10.1016/j.ecoleng.2013.07.023

16. Huang M, Wang Z, Qi R (2017) Enhancement of the complete autotrophic nitrogen removal over nitrite process in a modified single-stage subsurface vertical flow constructed wetland: effect of saturated zone depth. Bioresour Technol. 233 : 191-199. https://doi.org/10. 1016/j.biortech.2017.02.100

17. Hu Y, He F, Ma L, Zhang Y, Wu Z (2016) Microbial nitrogen removal pathways in integrated verticalflow constructed wetland systems. Bioresour Technol. $207: 339-345$. https://doi.org/10.1016/j.biortech.2016.01.106

18. Keene N A, Reusser S R, Scarborough M J, Grooms A L, Seib M, Santo Domingo J, Noguera D R (2017) Pilot plant demonstration of stable and efficient high rate biological nutrient removal with low dissolved oxygen conditions. Water Res. 121 : 72-85. https://doi.org/10.1016/j.watres.2017.05.029

19. Kim B, Gautier M, Prost-Boucle S, Molle P, Michel P, Gourdon R (2014) Performance evaluation of partially saturated vertical-flow constructed wetland with trickling filter and chemical precipitation for domestic and winery wastewaters treatment. Ecol Eng. $71: 41-47$. https://doi.org/10.1016/j.ecoleng.2014.07.045

20. Kim B, Gautier M, Palma G O, Molle P, Michel P, Gourdon R (2015a) Pilot-scale study of vertical flow constructedwetland combined with trickling filter and ferric chloride coagulation: influence of 
irregular operational conditions. Water Sci Technol. 71 : 1088-1096.

https://doi.org/10.2166/wst.2015.077

21. Kizito S, Lv T, Wu S, Ajmal Z, Luo H, Dong R (2017) Treatment of anaerobic digested effluent in biochar-packed vertical flow constructed wetland columns: Role of media and tidal operation, Sci Total Environ. 592 : 197-205. https://doi.org/10.1016/j.scitotenv.2017.03.125

22. Kotti I P, Gikas G D, Tsihrintzis V A (2010) Effect of operational and design parameters on removal efficiency of pilot-scale FWS constructed wetlands and comparison with HSF systems. Ecol Eng. 36 (7) : 862-875 .https://doi.org/10.1016/j.ecoleng.2010.03.002

23. Kraiem K., Kallali H, Wahab M A, Fra-Vazquez A, Mosquera-Corral A, Jedidi N (2019) Comparative study on pilots between ANAMMOX favored conditions in a partially saturated vertical flow constructed wetland and a hybrid system for rural wastewater treatment. Sci Total Environ. 670 : 644-653. https:// doi:10.1016/j.scitotenv.2019.03.220

24. Lavrova S, Koumanova B (2010) Influence of recirculation in a lab-scale vertical flow constructed wetland on the treatment efficiency of landfill leachate. Bioresour Technol. 101(6) : 1756-1761. https://doi.org/10.1016/j.biortech.2009.10.028

25. Li H, Tao W (2017) Efficient ammonia removal in recirculating vertical flow constructed wetlands: complementary roles of anammox and denitrification in simultaneous nitritation, anammox and denitrification process. Chem Eng J. 317 : 972-979. https://doi.org/10.1016/j.cej.2017.02.143

26. Liu H, Hu Z, Zhang J, Ngo H H, Guo W, Liang S, Fan J, Lu S, Wu H (2016) Optimizations on supply and distribution of dissolved oxygen in constructed wetlands: A review. Bioresour Technol. 214 : 797-805. https://doi.org/10.1016/j.biortech.2016.05.003

27. Mayo A W, Bigambo T (2005) Nitrogen transformation in horizontal subsurface flow constructed wetlands I: model development. Phys Chem Earth A/B/C. 30 (11-16) : 658667.https://doi.org/10.1016/j.pce.2005.08.005

28. Meng P, Pei H, Hu W, Shao Y, Li Z (2014) How to increase microbial degradation in constructed wetlands: influencing factors and improvement measures. Bioresour Technol. 157 : 316-326. https://doi.org/10.1016/j.biortech.2014.01.095

29. Moore J C, de Vries W, Lipp M, Grifiths J C, Abernethy D R (2010) Total Protein Methods and Their Potential Utility to Reduce the Risk of Food Protein Adulteration. Compr Rev Food Sci Food Saf. 9 (4) : 330-351. https://doi.org/10.1111/j.1541-4337.2010.00114.x

30. Paing J, Guilbert A, Gagnon V, Chazarenc F (2015) Effect of climate, wastewater composition, loading rates, system age and design on performances of French vertical flow constructed wetlands: A survey based on 169 full scale systems. Ecol Eng. $80: 46-52$. https://doi.org/10.1016/j.ecoleng.2014.10.029

31. Pelissari C, Ávila C, Trein C M, García J, Dultra de Armas R, Sezerino P H (2017) Nitrogen transforming bacteria within a full-scale partially saturated vertical subsurface flow constructed wetland treating urban wastewater. Sci Total Environ. 574 : 390-399. https://doi.org/10.1016/j.scitotenv.2016.08.207 
32. Pelissari C, Guivernau M, Vinas M, Garcia J, Velasco M, Souza S S, Sezerino P H, Avila C (2018) Effects of partially saturated conditions on the metabolically active microbiome and on nitrogen removal in vertical subsurface flow constructed wetlands. Water Research. 141 : 185-195. https://doi.org/10.1016/j.watres.2018.05.002

33. Platzer C (1999) Design recommendations for subsurface flow constructed wetlands for nitrification and denitrification. Water Sci Technol. 40 (3) : 257-263. https://doi.org/10.1016/S02731223(99)00420-5

34. Richardson D J (2000) Bacterial respiration: a flexibe process for a changing environment.Microbiology . 146 (3) : 551-571. https://doi.org/10.1099/00221287-146-3-551

35. Saeed T, Sun G (2011) Kinetic modelling of nitrogen and organics removal in vertical and horizontal flow wetlands. Water.Res. 45 (10) : 3137-3152. https://doi.org/10.1016/j.watres.2011.03.031

36. Saeed T, Sun G A (2012) review on nitrogen and organics removal mechanisms in subsurface flow constructed wetlands: dependency on environmental parameters, operating conditions and supporting media. J Environ Manag. 112 : 429-448. https://doi.org/10.1016/j.jenvman.2012.08.011

37. Silveira D D, Belli Filho P, Philippi L S, Kim B, Molle P (2015) Influence of partial saturation on total nitrogen removal in a single-stage French constructed wetland treating raw domestic wastewater. Ecol Eng. 77 : 257-264.https://doi.org/10.1016/j.ecoleng.2015.01.040

38. Stevens C J (2019) Nitrogen in the environment. Science. 363 (6427) : 578-580. https://doi.org/10.1126/science.aav8215

39. Torrijos V, Ruiz I , Soto M (2017) Effect of step-feeding on the performance of lab-scale columns simulating vertical flow-horizontal flow constructed wetlands. Environ Sci Pollut Res. 24 :1-14. https://doi.org/10.1007/s11356-017-9925-1

40. Vymazal J (2007) Removal of nutrients in various types of constructed wetlands. Sci Total Environ 380 (1-3) : 48-65. https://doi.org/10.1016/j.scitotenv.2006.09.014

41. Vymazal J, Kröpfelová L (2015) Multistage hybrid constructed wetland for enhanced removal of nitrogen. Ecol Eng. 84 : 202-208. https://doi.org/10.1016/j.ecoleng.2015.09.017

42. Wang Y, Wang J, Zhao X, Song, X, Gong, J (2016) The inhibition and adaptability of four wetland plant species to high concentration of ammonia wastewater and nitrogen removal efficiency in constructed wetlands. Bioresour Technol. 202 : 198-205.

https://doi.org/10.1016/j.biortech.2015.11.049

43. Wang J, Wang Y, Bai J, Liu Z, Song X, Yan D, Abiyu A, Zhao Z, Yan D (2017) High efficiency of inorganic nitrogen removal by integrating biofilm-electrodewith constructed wetland: autotrophic denitrifying bacteria analysis. Bioresour Technol. 227 : 7-14. https://doi.org/10.1016/j.biortech.2016.12.046

44. Wu H, Fan J, Zhang J, Hao H, Guo W, Liang S, Lv J, Lu S., Wu W, Wu S (2016) Intensified organics and nitrogen removal in the intermittent-aerated constructed wetland using a novel sludge ceramsite as substrate. Bioresour Technol. 210 : 101-107. https://doi.org/10.1016/j.biortech.2016.01.051 
45. Zhang Y, Cheng Y, Yang C, Luo W, Zeng G, Lu L (2015) Performance of system consisting of vertical flow trickling filter and horizontal flow multi-soil-layering reactor for treatment of rural wastewater. Bioresour Technol. 193 : 424-432 https://doi.org/10.1016/j.biortech.2015.06.140

46. Zhang N, Yang Y, Huang L, Xie H, Hu Z (2019) Birnessite-coated sand filled vertical flow constructed wetlands improved nutrients removal in a cold climate. RSC Adv. $9: 35931-35938$. https://doi.org/10.1039/c9ra07364g

47. Zwirglmaier K. (2005) Fluorescence in situ hybridisation (FISH) - the next generation. Mini review. FEMS. Microbiol Lett. 246 : 151-158. https://doi.org/10.1016/j.femsle.2005.04.015

\section{Figures}

Inlet

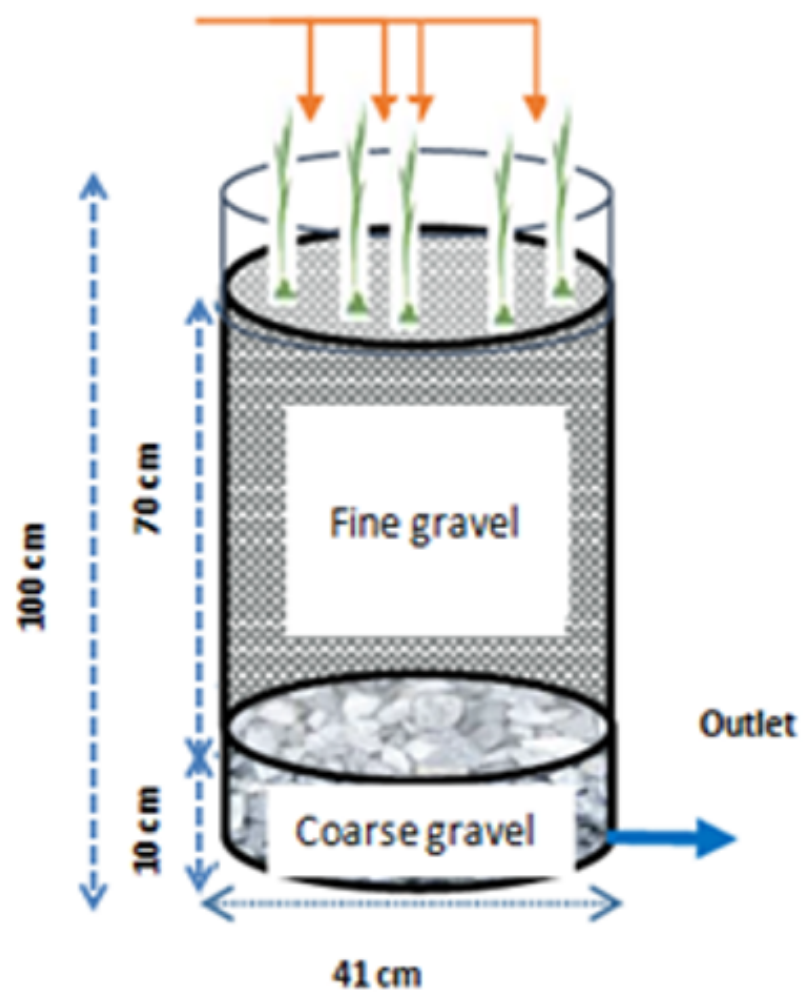

Inlet

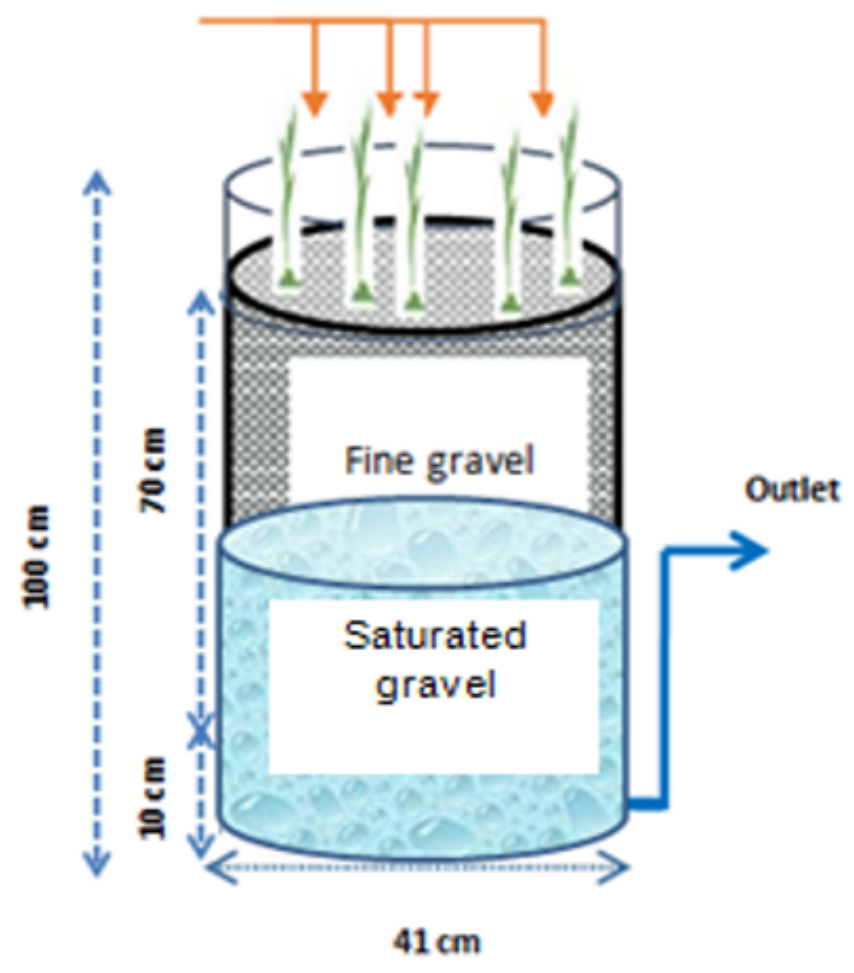

\section{Figure 1}

Schematic diagram for experimental constructed wetlands (CW). 

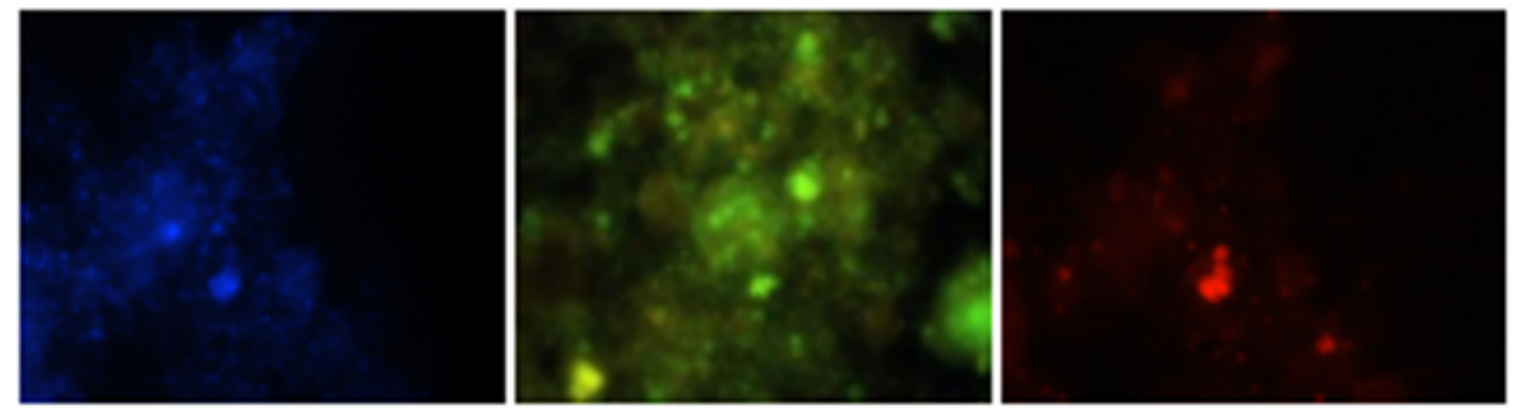

UVF-CW
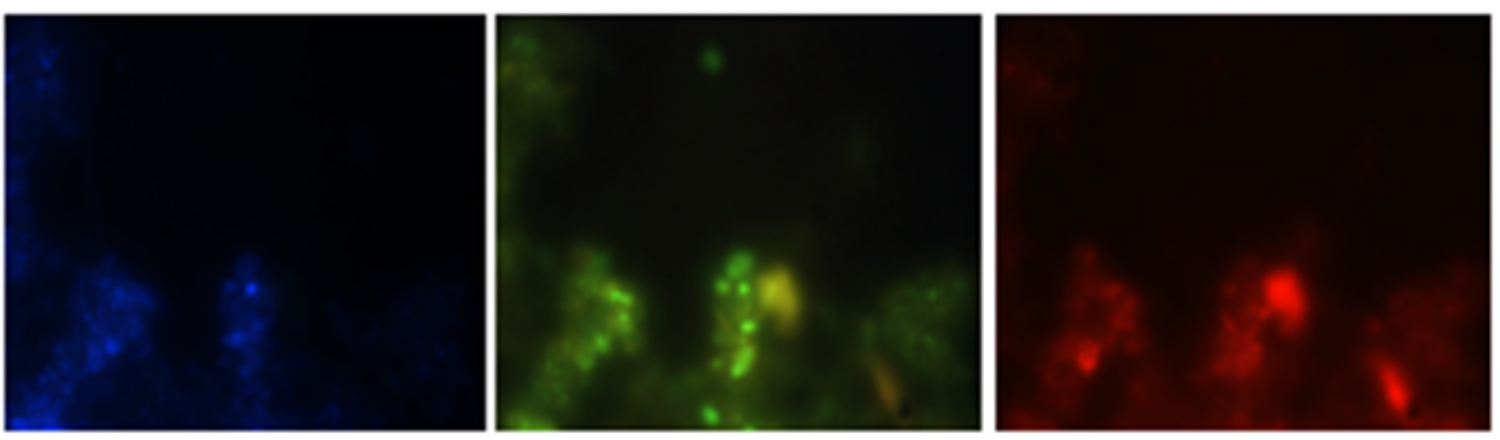

SVF-CW

Figure 2

FISH identification of nitrifying bacteria, DAPI (all DNA (blue)), middle, EUB338 mix probe (all bacteria (fluos, green)) right Nsv443 probe ( Nitrosospira (Cy3,red)).

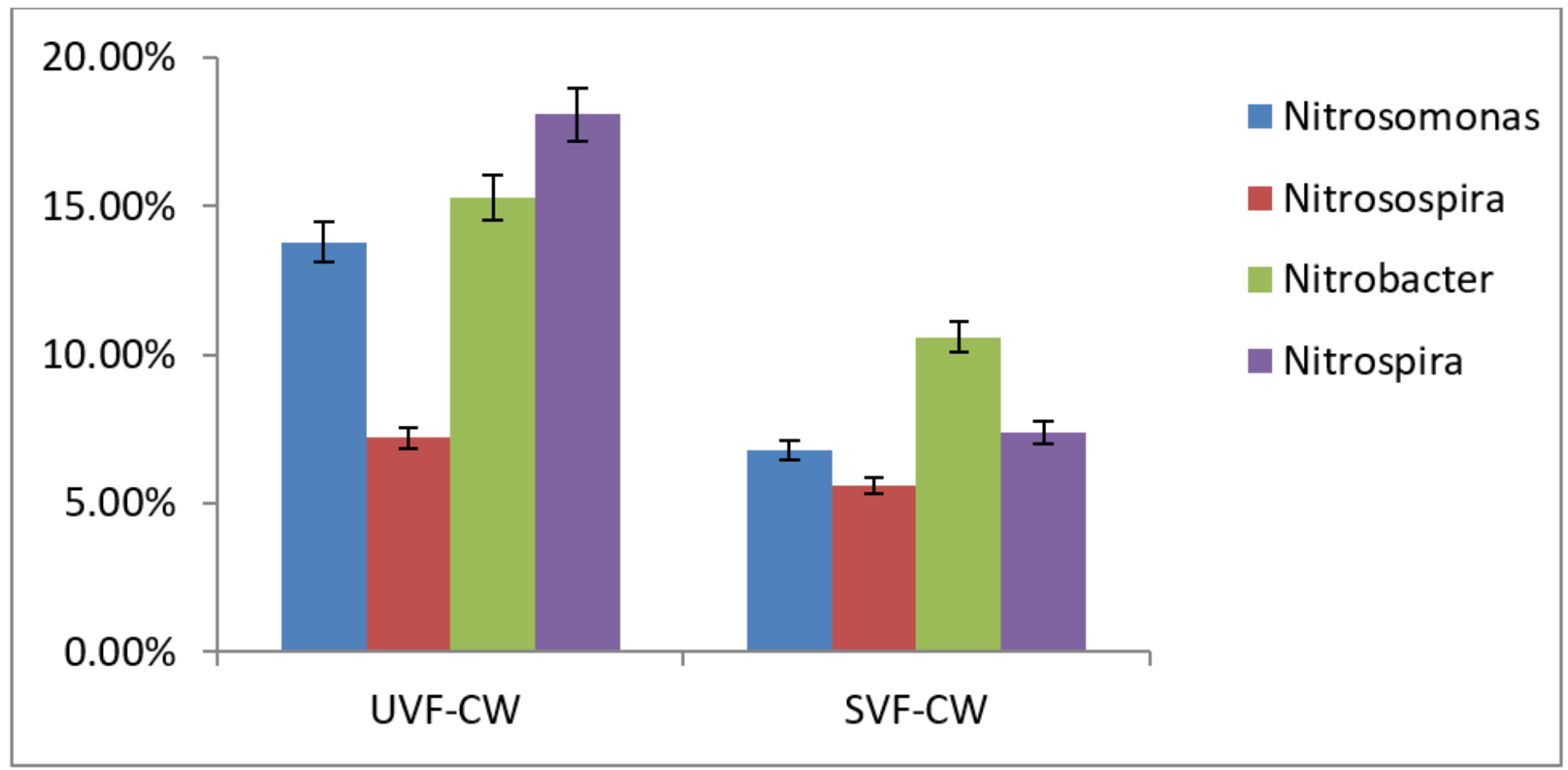

Figure 3

Relative abundance of nitrifying bacteria in UVF-CW and SVF-CW 


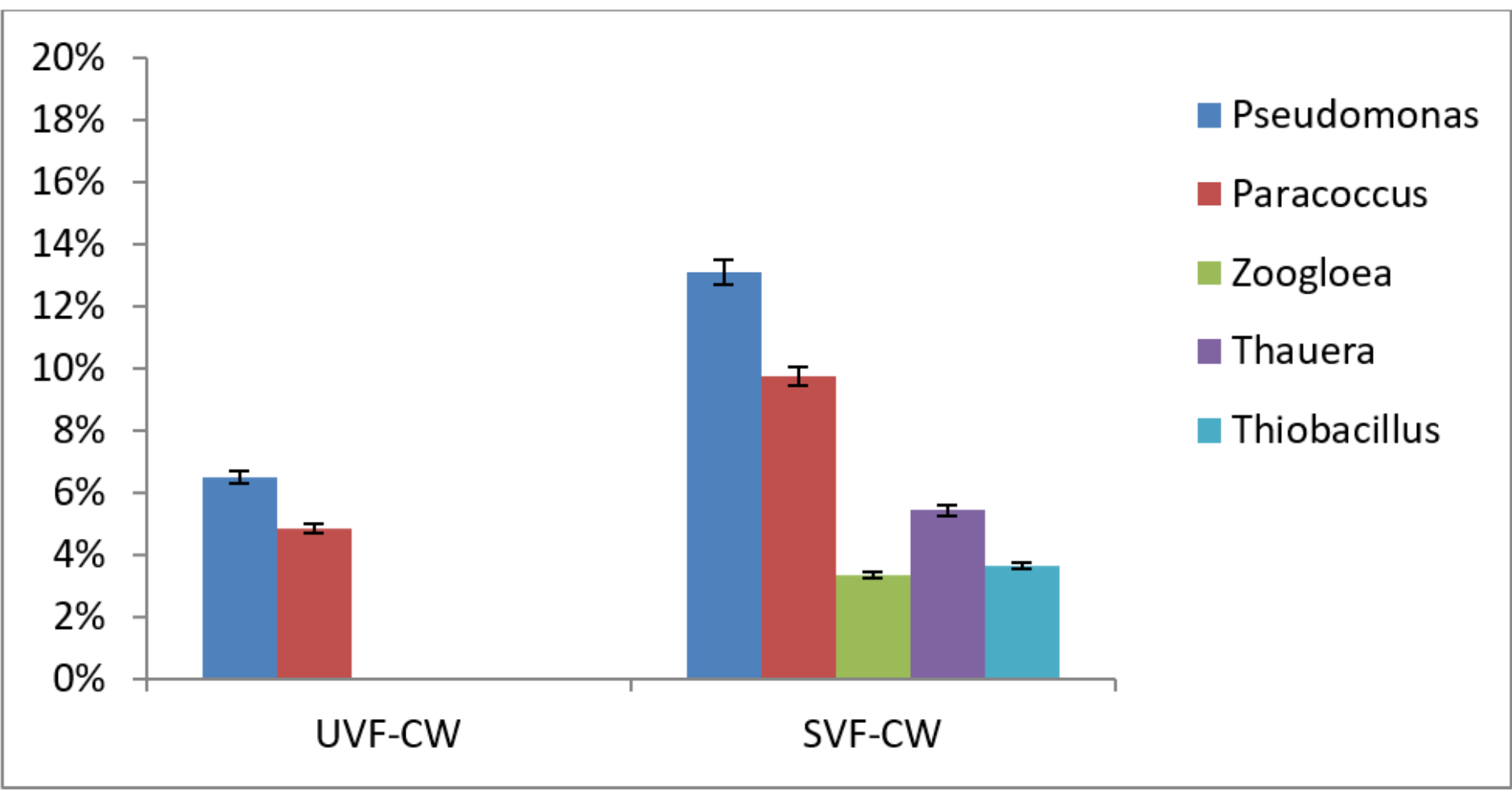

Figure 4

Relative abundance denitrifying bacteria in UVF-CW and SVF-CW

\section{Supplementary Files}

This is a list of supplementary files associated with this preprint. Click to download.

- GRAPHICALABSTRACT.docx 